ISSN 0103-5150

Fisioter. Mov., Curitiba, v. 28, n. 2, p. 407-418, Apr./June 2015

Licenciado sob uma Licença Creative Commons DOI: http://dx.doi.org.10.1590/0103-5150.028.002.AR02

\title{
Disability after stroke: a systematic review
}

\author{
Incapacidade após acidente vascular \\ cerebral: uma revisão sistemática
}

\section{Julia Fabres do Carmo ${ }^{[a]}$, Renato Lirio Morelato ${ }^{[\mathrm{b}]}$, Hudson Pereira Pinto ${ }^{[a]}$, Elizabete Regina Araujo de Oliveira ${ }^{[a] *}$}

[a] Universidade Federal do Espírito Santo (UFES), Vitória, ES, Brazil

${ }^{[b]}$ Escola de Medicina da Santa Casa de Misericórdia de Vitória (EMESCAM), Vitória, ES, Brazil

\begin{abstract}
Introduction: Stroke is the most common cause of disability in Western countries, yet there is no consensus in the literature on how to measure and describe disability from stroke. Objective: To conduct a systematic literature review on disability in stroke survivors. Method: Observational studies published in the PubMed, LILACS and SciELO online databases were selected, to evaluate disability in adults and in the elderly after stroke in the period 2002-2012. The Downs and Black checklist for non-randomized studies was used to assess the quality of the articles. Results: 212 articles were found from which 16 were selected to compose the study. The mean age of participants was 67 years, and disability affected $24 \%$ to $49 \%$ of the population evaluated. With regard to measurement instruments, $31 \%$ of the studies analyzed presented results of disability by means of the modified Rankin Scale; 19\% by means of the World Health Organization's International Classification of Functioning, Disability and Health; 19\% by means of Katz' Index of Independence in Activities of Daily Living; $12.5 \%$ by means
\end{abstract}

* JFC: MSc, e-mail: jufabres@ig.com.br RLM: PhD, e-mail: renato.morelato@emescam.br HPP: MSc, e-mail: pereira_hudson@hotmail.com ERAO: PhD, e-mail: elizabete_regina@hotmail.com 
of the London Handicap Scale; $12.5 \%$ by means of the Barthel Index; and $6.25 \%$ by means of the Functional Independence Measure. Conclusion: Literature is not uniform as regards means of measuring disability after stroke, but considering the preference of articles in assessing physical performance in activities of daily living, it can be concluded that a quarter to half of the population that survives stroke has some degree of disability.

Keywords: Stroke. Disabled persons. Disability evaluation.

\section{Resumo}

Introdução: $O$ acidente vascular cerebral (AVC) é a causa mais comum de incapacidade nos países ocidentais, e ainda não existe na literatura um consenso na forma de mensurar e descrever tal incapacidade. Objetivo: Realizar uma revisão sistemática da literatura sobre a incapacidade nos sobreviventes do AVC. Métodos: Foram selecionados estudos observacionais que avaliaram incapacidade na população adulta e idosa após AVC publicados na base de dados LILACS e nas bibliotecas virtuais PubMed e SciELO no período de 2002 a 2012. Para avaliação da qualidade dos artigos foi utilizado o critério de Downs e Black. Resultados: Foram encontrados 212 artigos e selecionados 16 para compor o banco de dados. A média de idade dos participantes foi de 67 anos e a incapacidade atingiu de 24\% a 49\% da população avaliada. Com relação aos instrumentos de mensuração, 31\% dos estudos analisados apresentaram os resultados de incapacidade por meio do Modified Rankin Scale, 19\% por meio da Classificação Internacional de Funcionalidade, 19\% por meio do Katz, 12,5\% por meio do London Handicap Scale, 12,5\% por meio do Barthel e 6,25\% por meio da Medida de Independência Funcional. Conclusão: A literatura não é uniforme quanto à forma de mensurar a incapacidade após AVC, mas considerando a preferência dos artigos em avaliar o desempenho físico nas atividades de vida diária, pode-se concluir que de um quarto à metade da população que sobrevive ao AVC apresenta algum grau de incapacidade.

Palavras-chave: Acidente vascular cerebral. Pessoas com deficiência. Avaliação da deficiência.

\section{Introduction}

Stroke is the term used for a group of diseases that have abrupt onset and cause neurological damage, and is the most common cause of disability in Western countries $(1,2,3)$. It is estimated that $25 \%$ to $74 \%$ of the 50 million stroke survivors in the world have some physical, cognitive or emotional deficiency, and require partial or complete assistance to carry out activities of daily living (ADL) (4). In recent years, advances in treatment of stroke reduced mortality rates, which, added to the phenomenon of aging, resulted in growth of the population that survives stroke (4-7).

Some theoretical models were created in order to explain and establish relationships between the concepts of deficiency, disability and need for assistance $(8,9,10)$. In one study that reviewed some of these models, Alves et al. (10) defined disability as a dynamic process that encompasses physical, mental and emotional conditions. Functional disability is understood as one part of this process, and is considered an indicator of disability, assessed by means of physical performance in daily activities $(10,11)$. Alves also brings together a variety of measurement instruments, demonstrating that in the literature there is still no single standard defined to measure disability.

Previous systematic reviews sought to identify predictive variables of good functional performance along with measurement instruments used to assess participation in survivors of stroke; however, no study searched by functional disability, considered a good indicator of disability $(11,12,13)$. The objective of this study was to systematically review the literature on disability after stroke, seeking to identify functional disability, variables associated with it, and disability measurement instruments used in this population.

\section{Method}

This was a systematic review of observational studies that adhered to the Cochrane Collaboration's 
online course recommendation of a prior search for systematic reviews on the topic in order to evaluate the need for the study. The search for reviews was performed in the Cochrane library and online using MEDLINE, with the following keywords: "systematic review", "stroke" and "disabled person" (14).

\section{Search strategy}

The search strategy for this review included research in three online databases: MEDLINE via PubMed (National Library of Medicine and National Institutes of Health); LILACS (Latin American and Caribbean Health Sciences Literature) and SciELO (Scientific Electronic Library Online). The key words used were matched in English and Portuguese, and registered in the National Library of Medicine's controlled vocabulary thesaurus (MeSH) and the Health Sciences Descriptors (Decs) trilingual thesaurus: "stroke" and "disabled persons" in English, and "acidente vascular cerebral" and "pessoa com deficiência" in Portuguese. The terms "disability" and "functional disability" were not used as descriptors because they were not registered in the Decs. The search period was January 2002 through December 2012, with no restriction on language.

\section{Selection of studies}

Titles and abstracts were read for initial selection of the articles identified. The full articles were then read, and those that met the inclusion criteria were included in the data collection phase, performed by means of a standardized form (Annex 1). Identification and selection of the studies was performed by two researchers working independently.

\section{Eligibility criteria}

The articles selected were observational and cross-sectional or cohort, with the aim of evaluating the disability or level of assistance required in adults and elderly individuals after suffering stroke. Studies that evaluated other outcomes in addition to disability were included; however, those that associated stroke with other clinical situations, or that compared specific interventions and methods of rehabilitation, were excluded. Articles that were not published in English, Portuguese or Spanish, and those that were not found even after attempting to contact the author were also excluded.

\section{Quality assessment}

The studies included were initially divided according to study design, and the longitudinal studies were evaluated for quality by adapting the Downs and Black checklist for non-randomized studies, using only the 13 items relating to assessment of cohort studies. Adaptation of the Downs and Black instrument has already been used in other reviews in order to identify relevant methodological features of observational studies $(15,16,17)$.

\section{Results}

The initial search yielded 212 documents; of these, 40 were selected. After reading each article in full, 24 were excluded for not meeting the eligibility criteria, leaving a total of 16 articles analyzed and submitted to the data collection phase of this review (Figure 1).

Among the studies analyzed, $56.25 \%$ were published since 2008. The articles were listed in descending order by year of publication in Table 1 , in which general data such as author/year, objective, study design, sample, participant age, instruments and results were summarized. Eight studies were cross-sectional, two of which presented results from the same Italian population. Eight studies were prospective longitudinal, of which two presented the results from one Australian cohort five and ten years after stroke.

Sample sizes ranged from 13 to 1233 subjects, with the mean being 254 participants of both sexes. The studies included adult populations of various age groups, and the mean participant age was 67 years. The moment of evaluation ranged from three months to ten years after stroke. Diagnostic criteria for definition of cases had some differences between studies: $68.7 \%$ conducted clinical examination and the patients were classified according to the International Classification of Diseases (ICD), and 50\% had the diagnosis reviewed by image examination. Three studies applied scales for disease classification: Lo et al. (18) used the National 


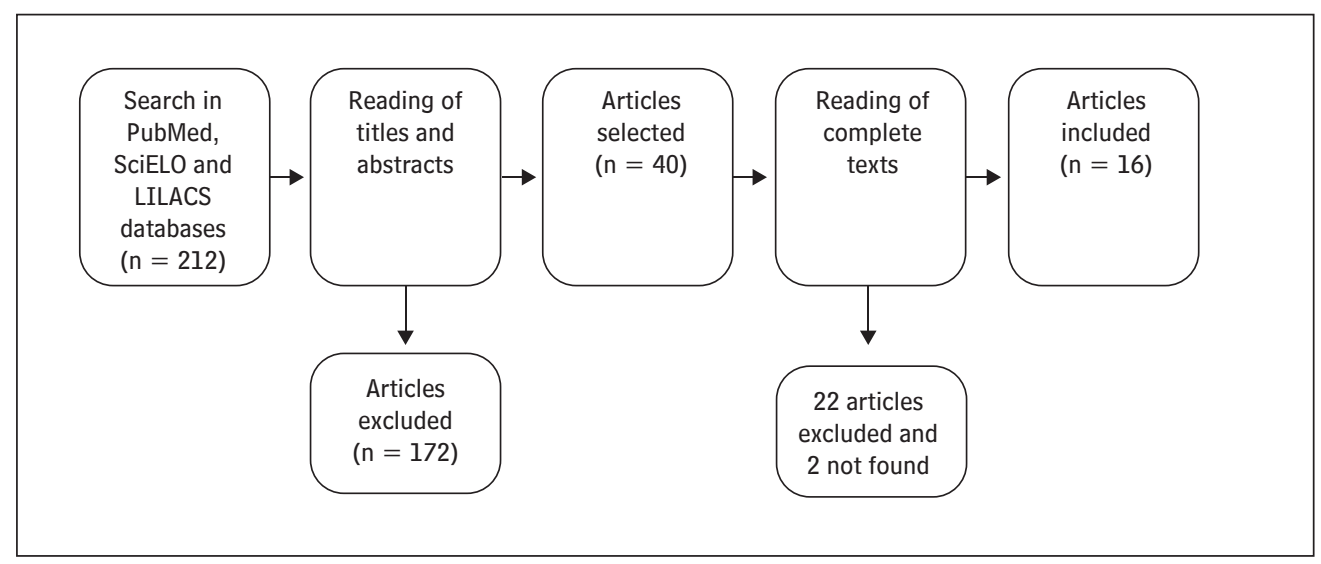

Figure $\mathbf{1}$ - Flowchart of the article inclusion process in the systematic review

Institute of Health Stroke Scale (NIHSS); Carod-Artal et al. (5) used the Trial of Org 10172 in Acute Stroke Treatment (TOAST); and Patel et al. (19) applied the Oxfordshire Community Stroke Project (OCSP). Three studies did not mention diagnostic criteria used $(6,17,20)$.

Four articles (25\%) set out to evaluate quality of life (QOL) in addition to disability, and found strong positive association between the physical domain of QOL instruments and disability $(5,7,17,19)$. Of the studies analyzed, $31 \%$ (five articles) presented the result of disability by means of the modified Rankin Scale (mRS) $(17,20,21,22,23) ; 19 \%$ (three articles) by means of the International Classification of Functioning, Disease and Health (ICF), one of which used the World Health Organization Disability Assessment Schedule (WHODAS 2.0) (7, 24, 25); $19 \%$ (three articles) by means of the Katz Index of Independence in Activities of Daily Living $(6,26,27)$;
$12.5 \%$ (two articles) by means of the London Handicap Scale $(18,28) ; 12.5 \%$ (two articles) by means of the Barthel Index $(5,19)$; and $6.25 \%$ (one article) according to the Functional Independence Measure (FIM) (29).

Considering functional disability as an indicator of disability measured by means of instruments such as the Katz and Barthel scales and the mRS, the result of 12 of the 16 selected articles can be assembled as follows: in the first two years after stroke, disability affected $24 \%$ to $49 \%$ of the population evaluated; three to five years after stroke, that number was between $26 \%$ and $47 \%$; and ten years after, $46 \%$ of the population had some level of disability.

The evaluation of quality applied to the cohort studies had a mean methodological score of 10.5, and the studies that obtained the highest score were Hardie et al. (23) and Lin et al. (29). The score of each study can be found in Table 1 .

Table 1- Characteristics of studies selected

(To be continued)

\begin{tabular}{|c|c|c|c|c|c|c|}
\hline $\begin{array}{l}\text { Reference } \\
\text { year/location }\end{array}$ & Objective & $\begin{array}{l}\text { Study } \\
\text { design }\end{array}$ & No. & $\begin{array}{l}\text { Mean age } \\
\text { (years) }\end{array}$ & Measurement & Result \\
\hline $\begin{array}{l}\text { Cerniauskaite } \\
\text { et al. (7) } \\
2012 \\
\text { Italy }\end{array}$ & $\begin{array}{l}\text { To assess impact } \\
\text { of stroke on quality } \\
\text { of life and disability, } \\
\text { and the relationship } \\
\text { between both. }\end{array}$ & $\begin{array}{l}\text { Cross- } \\
\text { sectional }\end{array}$ & 111 & 57 & $\begin{array}{l}\text { SF-36 } \\
\text { WHODAS } 2.0\end{array}$ & $\begin{array}{l}53 \% \text { reported that there was no } \\
\text { change in health after the stroke; } \\
\text { however the SF- } 36 \text { score was lower } \\
\text { when compared with the general } \\
\text { population. Strong correlation ( } p \\
=0.84 \text { and } 0.75 \text { ) in the physical } \\
\text { function domains of the SF-36 } \\
\text { with the areas of mobility and } \\
\text { domestic tasks, respectively, of the } \\
\text { WHODAS }(p<0.01 \text { ). }\end{array}$ \\
\hline
\end{tabular}


Table 1- Characteristics of studies selected

(To be continued)

\begin{tabular}{|c|c|c|c|c|c|c|}
\hline $\begin{array}{l}\text { Reference } \\
\text { year/location }\end{array}$ & Objective & $\begin{array}{l}\text { Study } \\
\text { design }\end{array}$ & No. & $\begin{array}{l}\text { Mean age } \\
\text { (years) }\end{array}$ & Measurement & Result \\
\hline $\begin{array}{l}\text { Quintas et al. } \\
(24) \\
2012 \\
\text { Italy }\end{array}$ & $\begin{array}{l}\text { To demonstrate } \\
\text { that stroke alone } \\
\text { does not explain } \\
\text { the differences and } \\
\text { variety of function } \\
\text { and disability. }\end{array}$ & $\begin{array}{l}\text { Cross- } \\
\text { sectional }\end{array}$ & 111 & 57 & ICF & $\begin{array}{l}47 \% \text { reported moderate to severe } \\
\text { gait compromise, and } 25 \% \text { in } \\
\text { speaking and understanding. The } \\
\text { most reported problems of body } \\
\text { function were: function of memory, } \\
\text { attention and muscles. In the } \\
\text { environment component: family } \\
(92 \%) \text { and healthcare professionals } \\
(82 \%) \text { are the main facilitators. }\end{array}$ \\
\hline $\begin{array}{l}\text { Martins et al. } \\
(25) \\
2011 \\
\text { Brazil }\end{array}$ & $\begin{array}{l}\text { To describe profiles of } \\
\text { disability and function } \\
\text { by combining use of } \\
\text { the ICD and ICF to } \\
\text { evaluate survivors of } \\
\text { stroke. }\end{array}$ & $\begin{array}{l}\text { Cross- } \\
\text { sectional }\end{array}$ & 13 & 73 & $\begin{array}{l}\text { ICD } \\
\text { ICF }\end{array}$ & $\begin{array}{l}69 \% \text { were classified as hemiplegic, } \\
\text { and } 31 \% \text { hemiparetic. Of events } \\
\text { coded by means of the ICF, the } \\
\text { most reported body function } \\
\text { problems were: movement function } \\
(34 \%) \text {, neuromuscular (27\%) and } \\
\text { damage to structures related to } \\
\text { movement. } \mathbf{5 2} \% \text { had compromise } \\
\text { in activities and participation, } \\
\text { mainly in daily domestic activities } \\
\text { and tasks. }\end{array}$ \\
\hline $\begin{array}{l}\text { Hong et al. } \\
\text { (22) } \\
2010 \\
\text { South Korea }\end{array}$ & $\begin{array}{l}\text { To apply the DALY } \\
\text { measure to quantify } \\
\text { years of life lost due } \\
\text { to disability. }\end{array}$ & $\begin{array}{l}\text { Cross- } \\
\text { sectional }\end{array}$ & 1233 & 66 & $\begin{array}{l}\text { NIHSS } \\
\text { mRS } \\
\text { DALY }\end{array}$ & $\begin{array}{l}35 \% \text { were considered dependent } \\
\text { for activities of daily living (mRS } \\
3-6 \text { ). The mean of years lost due } \\
\text { to disability was } 3.82 \text { (IC } 95 \% 3.68 \\
\text { to } 3.96 \text { ). }\end{array}$ \\
\hline $\begin{array}{l}\text { Coss et al. (6) } \\
2010 \\
\text { Cuba }\end{array}$ & $\begin{array}{l}\text { To evaluate } \\
\text { independence index } \\
\text { in patients after } \\
\text { stroke }\end{array}$ & $\begin{array}{l}\text { Cross- } \\
\text { sectional }\end{array}$ & 22 & 30-90 & Katz & $\begin{array}{l}45 \% \text { were aged } 70 \text { to } 90 \text { years. } \\
\mathbf{4 1 \%} \text { were dependent for at least } \\
\text { one of the six activities evaluated. } \\
4.5 \% \text { were dependent for all } \\
\text { activities. }\end{array}$ \\
\hline $\begin{array}{l}\text { Carod-Artal et } \\
\text { al. (5) } \\
2009 \\
\text { Brazil }\end{array}$ & $\begin{array}{l}\text { To identify the } \\
\text { determinants of } \\
\text { quality of life in } \\
\text { survivors of stroke. }\end{array}$ & $\begin{array}{l}\text { Cross- } \\
\text { sectional }\end{array}$ & 260 & 55 & $\begin{array}{l}\text { Barthel } \\
\text { Lawton } \\
\text { SIS } \\
\text { NIHSS } \\
\text { mRS }\end{array}$ & $\begin{array}{l}31.5 \% \text { had severe disability } \\
\text { (Barthel } \leq 60) \text { and } 35 \% \text { moderate } \\
\text { disability (Barthel } 65-90) .49 \% \\
\text { were evaluated with mRS } \geq 3 . \text { Age } \\
\text { ( } r=-0.20 \text { ) and presence of other } \\
\text { comorbidities ( } r=0.35 \text { ) were } \\
\text { correlated to level of dependency. } \\
(p<0.0001) \text {. Disability (Barthel) } \\
\text { has high correlation with the } \\
\text { physical domain of the SIS } \\
(r=0.99) \text {. }\end{array}$ \\
\hline $\begin{array}{l}\text { Petrea et al. } \\
2009 \\
\text { USA }\end{array}$ & $\begin{array}{l}\text { To explore gender } \\
\text { difference in post- } \\
\text { stroke disability and } \\
\text { incidence in the } \\
\text { Framingham Cohort. }\end{array}$ & Cohort & 205 & $45-94$ & Katz & $\begin{array}{l}\text { Women are } 4 \text { times more likely than } \\
\text { men to be dependent prior to stroke } \\
(\mathrm{OR}=4.3, p<0.001) \text { and six } \\
\text { months after }(\mathrm{OR}=3.7) .32 \% \text { of } \\
\text { women presented dependence for } \\
\text { transfer, and } 37 \% \text { for walking. For } \\
\text { men these percentages were } 13 \% \\
\text { and } 18 \% \text {, respectively (OR }=2.3 \text {, } \\
\mathrm{OR}=1.91) \text {. Quality score: } 11 .\end{array}$ \\
\hline
\end{tabular}


Table 1- Characteristics of studies selected

(To be continued)

\begin{tabular}{|c|c|c|c|c|c|c|}
\hline $\begin{array}{l}\text { Reference } \\
\text { year/location }\end{array}$ & Objective & $\begin{array}{l}\text { Study } \\
\text { design }\end{array}$ & No. & $\begin{array}{l}\text { Mean age } \\
\text { (years) }\end{array}$ & Measurement & Result \\
\hline $\begin{array}{l}\text { Gall et al. (28) } \\
2008 \\
\text { Australia }\end{array}$ & $\begin{array}{l}\text { To define standard } \\
\text { and level, and } \\
\text { identify risk factors } \\
\text { of disability five years } \\
\text { after stroke. }\end{array}$ & Cohort & 352 & 75 & $\begin{array}{l}\text { Barthel LHS; } \\
\text { IDA }\end{array}$ & $\begin{array}{l}45 \% \text { of the cohort survived } 5 \\
\text { years after stroke. Of those who } \\
\text { survived, } 70 \% \text { are among the } \\
\text { deciles representing disability (LHS } \\
<90 \text { ), mainly in the domains of } \\
\text { physical independence, leisure } \\
\text { and occupation. } \mathbf{4 7 \%} \text { showed } \\
\text { dependence in some BADL } \\
\text { (Barthel). Increasing age and } \\
\text { recurrence of stroke are factors } \\
\text { associated with greater disability. } \\
\text { Quality score: } 9 \text {. }\end{array}$ \\
\hline $\begin{array}{l}\text { Lo et al. (18) } \\
2008 \\
\text { China }\end{array}$ & $\begin{array}{l}\text { To investigate } \\
\text { changes in levels of } \\
\text { disability in survivors } \\
\text { of stroke, and identify } \\
\text { their determinants. }\end{array}$ & Cohort & 268 & 77 & $\begin{array}{l}\text { Barthel Lawton } \\
\text { MMSE } \\
\text { GDS } \\
\text { LHS }\end{array}$ & $\begin{array}{l}\text { Three months after stroke, } 24 \% \\
\text { were dependent in more than } \\
\text { one BADL (Barthel }<14 \text { ) and } \\
\mathbf{3 0 \%} \text { was in the range } 15 \text { to } 19 \text {. } \\
19 \% \text { were institutionalized. In the } \\
\text { multilevel analysis, depression } \\
\text { (GDS), functional disability (Barthel) } \\
\text { and advancement of age were } \\
\text { strongly associated with disability } \\
\text { and severity (LHS) } p<0.001 \text {. } \\
\text { Quality score: } 10 \text {. }\end{array}$ \\
\hline $\begin{array}{l}\text { Appelros et al. } \\
\text { (20) } \\
2006 \\
\text { Sweden }\end{array}$ & $\begin{array}{l}\text { To verify the living } \\
\text { scenario and need for } \\
\text { assistance for } A D L \\
\text { before and one year } \\
\text { after stroke. }\end{array}$ & Cohort & 253 & 75 & $\begin{array}{l}\text { Barthel } \\
\text { FAl } \\
\text { mRS } \\
\text { GDS } \\
\text { MMSE NIHSS }\end{array}$ & $\begin{array}{l}37 \% \text { of the cohort presented MRS } \\
\geq 3 \text {. Before the stroke, } 13 \% \text { lived } \\
\text { in institutions; one year after the } \\
\text { stroke, } 20 \% \text { lived in institutions, } \\
\text { and the factors associated with this } \\
\text { change were prior dependency (OR } \\
=17 \text { ), cognitive impairment (OR = } \\
\text { 12) and depression (OR }=4.5) \text { p } \\
<0.001 \text {. One year after the event, } \\
\mathbf{3 6} \% \text { of stroke survivors needed } \\
\text { some help with BADL, and } 59 \% \\
\text { required help with BADL. Quality } \\
\text { score: } 10 \text {. }\end{array}$ \\
\hline $\begin{array}{l}\text { Patel et al. (19) } \\
2006 \\
\text { England }\end{array}$ & $\begin{array}{l}\text { To estimate level } \\
\text { of disability and } \\
\text { quality of life three } \\
\text { years after stroke, } \\
\text { and examine the } \\
\text { relationship between } \\
\text { the two domains. }\end{array}$ & Cohort & 490 & 71 & $\begin{array}{l}\text { Barthel } \\
\text { FAl } \\
\text { SF-36 }\end{array}$ & $\begin{array}{l}\text { Three years after the stroke, } \\
\mathbf{3 4 \%} \text { were independent and } \mathbf{2 6 \%} \\
\text { were moderately to severely } \\
\text { disabled (Barthel }<15) \text {. } 51 \% \\
\text { were inactive (FAI }<15) \text {. Strong } \\
\text { correlation }(r=0.79) \text { between } \\
\text { FAI and Barthel and strong } \\
\text { correlation }(r>0.70) \text { between } \\
\text { the physical domain of the } \\
\text { HRQOL and disability (Barthel). } \\
\text { Quality score: } 11 \text {. }\end{array}$ \\
\hline
\end{tabular}


Table 1- Characteristics of studies selected

(Conclusion)

\begin{tabular}{|c|c|c|c|c|c|c|}
\hline $\begin{array}{l}\text { Reference } \\
\text { year/location }\end{array}$ & Objective & $\begin{array}{l}\text { Study } \\
\text { design }\end{array}$ & No. & $\begin{array}{l}\text { Mean age } \\
\text { (years) }\end{array}$ & Measurement & Result \\
\hline $\begin{array}{l}\text { Martins et al. } \\
(17) \\
2006 \\
\text { Portugal }\end{array}$ & $\begin{array}{l}\text { To evaluate the } \\
\text { impact of stroke on } \\
\text { quality of life and } \\
\text { functional capacity } \\
\text { nine months after } \\
\text { hospital discharge. }\end{array}$ & $\begin{array}{l}\text { Cross- } \\
\text { sectional }\end{array}$ & 273 & 69 & $\begin{array}{l}\text { Barthel } \\
\text { FAl } \\
\text { mRS } \\
\text { COOP/WONCA }\end{array}$ & $\begin{array}{l}36 \% \text { of the sample was } \\
\text { independent in BADL (Barthel), } \\
47 \% \text { had disability ( } m R S \geq 3) \text {, } \\
\text { and } 29 \% \text { were self-employed in } \\
\text { IADL (FAI). Perception of quality of } \\
\text { life }(Q 0 L) \text { is strongly associated } \\
(0.70, p<0.01 \text { ) with functional } \\
\text { capacity, the domain physical } \\
\text { fitness was the most affected in } \\
\text { the assessment of } Q 0 L \text {. }\end{array}$ \\
\hline $\begin{array}{l}\text { Lin et al. (29) } \\
2005 \\
\text { China }\end{array}$ & $\begin{array}{l}\text { To identify predictors } \\
\text { of degree of disability } \\
\text { one year after stroke. }\end{array}$ & Cohort & 109 & 62 & FIM & $\begin{array}{l}\text { The group classified with severe } \\
\text { and very severe disability ( } 59 \%) \\
\text { presented a mean FIM score of } 65 \\
\text { and the group with mild to moderate } \\
\text { disability }(41 \%) \text { showed mean FIM } \\
\text { score of } 87 . \text { In the regression model, } \\
\text { bilateral involvement (OR }=10.8) \\
\text { and low FIM score (OR }=7.6) \text { were } \\
\text { associated with the highest level of } \\
\text { disability. Quality score: } 12\end{array}$ \\
\hline $\begin{array}{l}\text { Hardie et al. } \\
(23) \\
2004 \\
\text { Australia }\end{array}$ & $\begin{array}{l}\text { To determine } \\
\text { frequency of } \\
\text { recurrence of stroke } \\
\text { and disability } 10 \\
\text { years after first } \\
\text { stroke. }\end{array}$ & Cohort & 45 & 72 & $\mathrm{mRS}$ & $\begin{array}{l}10 \text { years after the first stroke: } \\
\text { approximately } 15 \% \text { were } \\
\text { institutionalized, } 46 \% \text { were } \\
\text { incapacitated. The risk of suffering } \\
\text { from another stroke among the } \\
\text { subjects of the cohort was } 6 \text { times } \\
\text { greater than the general population, } \\
\text { even after adjusting for sex and age } \\
\text { (95\% IC }-4.5-7.4) \text {.Quality score: } 12 \text {. }\end{array}$ \\
\hline $\begin{array}{l}\text { Widar et al. } \\
(26) \\
2002 \\
\text { Sweden }\end{array}$ & $\begin{array}{l}\text { To describe disability } \\
\text { and pain in everyday } \\
\text { life of survivors who } \\
\text { cite pain after stroke. }\end{array}$ & $\begin{array}{l}\text { Cross- } \\
\text { sectional }\end{array}$ & 43 & $33-82$ & $\begin{array}{l}\text { Katz } \\
\text { MPI-S }\end{array}$ & $\begin{array}{l}46 \% \text { were dependent for one or } \\
\text { more BADL (Katz). } 52 \% \text { reported } \\
\text { difficulties walking, and } 50 \% \\
\text { depended on mobility equipment. } \\
63 \% \text { reported moderate pain, } 37 \% \\
\text { reported severe pain. }\end{array}$ \\
\hline $\begin{array}{l}\text { Hankey et al. } \\
(21) \\
2002 \\
\text { Australia }\end{array}$ & $\begin{array}{l}\text { To describe disability } \\
\text { and dependence five } \\
\text { years after stroke in } \\
\text { the city of Perth. }\end{array}$ & Cohort & 277 & 73 & $\begin{array}{l}\text { Barthel } \\
\text { FAI } \\
\text { mRS } \\
\text { Motrlnd }\end{array}$ & $\begin{array}{l}19 \% \text { had some disability before } \\
\text { the stroke. } 45 \% \text { of the cohort } \\
\text { had died five years after the first } \\
\text { stroke, } 17.7 \% \text { of the survivors } \\
\text { were institutionalized, and } 36 \% \text { had } \\
\text { some dependency for BADL. The } \\
\text { cumulative risk of a new and greater } \\
\text { disability was } 36 \% \text {. The prognostic } \\
\text { factors of disability were old age } \\
\text { (OR }=5.7 \text { in the age range } 75-84 \text { ), } \\
\text { recurrence of stroke and apathy in } \\
\text { the first evaluation. Quality score: } 9 \text {. }\end{array}$ \\
\hline
\end{tabular}

Note: SF-36 = Short Form Health Survey; WHODAS $2.0=$ World Health Organization Disability Assessment Schedule 2.0; ICF $=$ International Classification of Functioning, Disability and Health; ICD = International Classification of Diseases; NIHSS = National Institute of Health Stroke Scale; $\mathrm{mRS}$ = modified-Rankin Scale; DALY = disability adjusted life year; SIS = Stroke Impact Scale; LHS = London Handicap Scale; IDA = Irritability, Depression and Anxiety; MMSE = Mini-Mental State Examination; GDS = Geriatric Depression Scale; FAI = Frenchay Activities Index; COOP/WONCA = Primary Care Cooperative Information Project/World Organization of National Colleges Academies; MPI-S $=$ Multidimensional Pain Inventory; Motrlnd $=$ Motricity Index. 


\section{Discussion}

Measurement instruments and results of disability

The studies applied various measurement instruments. Appelros et al. (20) used the Barthel Index, but presented the result of the disability by means of the mRS, concluding that $37 \%$ of the cohort was disable (mRS 3-6). Martins et al. (17) used the same methodology, and concluded that $36 \%$ of the sample was independent in Basic Activities of Daily Living (BADL) through Barthel Index, but $47 \%$ had disability ( $m R S \geq 3$ ).

Hong et al. (22) applied the disability-adjusted life year (DALY) measure to survivors of stroke, and used the results of the mRS for the calculation. As 35\% of participants were disabled (mRS 3-6), the mean number of years of life lost due to disability was 3.82 (CI 95\% 3.68 to 3.96). Hankey et al. (21) and Hardie et al. (23) also used the modified Rankin Scale (mRS) to present the results of disability.

Of the seven studies that applied the Barthel Index (BI), five used a modified version of the instrument with scoring from 0 to $20(17,18,19,21,28)$. Despite being the most applied instrument among the studies, only two presented the results of disability using the BI: the English cohort of Patel et al. (19) showed $12 \%$ with severe disability (BI < 9), $14 \%$ moderate (BI 10-14), 34\% mild (15-19), whereas 39\% were independent $(\mathrm{BI}=20)$. The Brazilian study by CarodArtal et al. (5) used the original scoring proposal from 0 to 100 , and determined that $34 \%$ of the subjects were independent, $31 \%$ had severe disability (BI $\leq$ $60)$, and $35 \%$ moderate disability (BI $=65-90)$.

The other studies used the BI to classify level of dependence, including Lo et al. (18), who showed results of disability with the London Handicap Scale, but classified dependence in two levels: $24 \%$ had $\mathrm{BI}<14$, which is dependency in more than one BADL, and 30\% were in the Barthel range 15-19.

The Australian studies by Gall et al. (28) and Hankey et al. (21) evaluated people five years after the first stroke, and also used other instruments to present disability; however, they applied the BI and defined as dependent those subjects who had a score $<20$, and found $36 \%$ and $47 \%$ of their subjects dependent in some BADL, respectively.
Petrea et al. (27), Coss et al. (6) and Widar et al. (26) used the Katz Index in their reviews, and respectively found that $45 \%, 41 \%$ and $46 \%$ of their samples was dependent on at least one of the six activities evaluated. Lin et al. (29) used the Functional Independence Measure (FIM), and classified 59\% of the sample with severe and very severe disability (mean score of 65 ), and $41 \%$ with moderate and mild disability (mean score of 87). In addition to evaluating the need for assistance with BADL and mobility, the FIM also evaluates communication and cognition.

The International Classification of Functioning, Disability and Health (ICF) was used in three studies $(7,24,25)$. Quintas et al. (24) showed that body function problems most frequently reported by subjects that suffer from stroke are: difficulties with memory (more than 50\% of the sample), attention (approximately $50 \%$ ) and muscle function strength (50\% of the sample). Furthermore, $47 \%$ reported moderate to severe gait impairment. Martins et al. (25) observed that $34 \%$ of subjects had difficulty in functions related to movement, and $52 \%$ had limitations in activities and participation, especially in domestic activities.

This result corroborates Alves (10), who also showed absence of a well-defined standard to measure disability. The terms "disability" and "level of dependency" were constantly taken alternatively in the articles, instruments such as Barthel and Katz, which were developed to assess level of dependence in ADL, were used to present the results of disability. Guccione (30) and Alves (31) point out that these scales of difficulty and dependence are good instruments for measuring functional disability, which is an aspect of disability. This result shows that there is a preference in the literature for measuring disability according to physical performance in daily activities, a result already observed by Cerniauskaite et al. (7). However, the approach of the ICF warns that disability cannot only be evaluated by dependence in ADL. The WHODAS 2.0, a disability assessment scale created by the WHO, evaluates the individual's functioning in six areas of activity: understanding and communicating, physical mobility, self-care, living with people, life activities and participation in society. It seems to be an instrument capable of covering all domains of disability, but because of its recent publication, it had little reference in the studies (32). 
Variables associated with disability and types of analysis

The results of four cohorts brought variables that were predictive or associated with disability. Gall et al. (28), by means of multivariate regression analysis, found that five years after stroke, increasing age and the recurrence of stroke $(\mathrm{P}<0.01)$ were associated with greater disability. The Perth cohort also identified advanced age (OR $=5.7$ in the age range 75-84; CI 95\% 1.7-18.9), stroke recurrence (OR $=14.4, \mathrm{CI} 95 \%$ CI 3.3-63), and moderate hemiparesis (OR $=3.4$; CI 95\% 1.2-9.5) as prognostic factors of disability, using logistic regression analysis adjusting the sex (23).

Using the logistic regression model, Lin et al. (29) found that bilateral compromise (OR $=10.8$, $\mathrm{p}<0: 02$ ) and low FIM score (OR = 7.6, p < 0.008) are the main variables associated with disability. Lo et al. (18) used the multilevel analysis and concluded that depression, advancing age and level of dependence are strongly associated with disability and severity $(\mathrm{p}<0.001)$.

Petrea et al. (27) explored gender difference in post-stroke disability in Framingham's cohort, by means of bivariate analysis and logistic regression for variable adjustments considered risk factors for stroke according to Framingham. The authors found that women are four times more likely to be dependent prior to stroke than men $(\mathrm{OR}=4.3, \mathrm{p}<$ 0.01 ), and six months after stroke the chances of dependency remain higher in women $(\mathrm{OR}=3.7$, $\mathrm{p}<0.01$ ).

Five cohorts assessed the institutionalization rate of stroke survivors. Appelros et al. (20) aimed to define changes in living scenario, and found that prior to stroke, $13 \%$ lived in special housing, and one year after stroke that number had risen to $20 \%$. The Perth cohort showed that five years after stroke, $17.7 \%$ of its members were institutionalized, and ten years after, $15 \%$ of the surviving members were institutionalized $(21,23)$. Lo et al. (18) found that $19 \%$ of its population was institutionalized three months after stroke. The study that explored gender differences in the Framingham cohort found that women are 3.5 times more likely ( $p<0.01$ ) to be institutionalized six months after stroke than men (rate of $35 \%$ for women and $10 \%$ for men) (27).
Disability in time

Functional capacity decreases with time, whereas the risk of developing a chronic condition increases (33). The debilitating process proceeds through the evolution of the chronic condition associated with other factors such as lifestyle, behavior, and biological, social and demographic characteristics (34).

Four cohorts followed the patients during the first year after stroke. Petrea et al. (27) found that three months after the event, the level of incapacity was greater than when compared after six months. Lo et al. (18) had a similar result, and concluded that its participants were less disabled after one year than in the third month, suggesting that functionality can improve between the third and twelfth month after stroke. This finding is consistent with previous articles that report a recovery between the third and sixth month after stroke $(35,36)$.

Most of the cross-sectional studies did not define the exact moment after stroke, and assessed subjects at various times $(5,6,7,24)$, while $19 \%$, four cohorts, investigated long-term disability. Hankey et al. (21) stated that disability and institutionalization are the most common long-term results, affecting one-third and one-seventh of the survivors respectively. These authors also consider that the most important modifiable prognostic factors for these results are the low levels of physical activity and recurrence of stroke. Patel et al. (19) found that five years after stroke, 36\% of the survivors of their cohort were dependent in some way. Gall et al. (28) found a similar result, where $47 \%$ of the survivors were dependent for some ADL after five years.

Evaluation of methodological quality and limitations of the study

The methodological variation between the studies, such as period evaluated, measurement instruments used and the form of data presentation made it difficult to gather the results of the 16 articles. Although the eight longitudinal studies evaluated had good methodological quality within the criteria of Downs and Black, the studies with cross-sectional design were not evaluated due to lack of scale or criterion for this purpose, which can be considered a limitation 
of this study. In addition, four articles were excluded from the study, two because they were not found, and two due to language.

\section{Conclusion}

This systematic review revealed heterogeneity in the literature when the subject is disability among stroke survivors. Most studies evaluated aspects of disability, failing to include all domains involved in this phenomenon. Furthermore, there is still no consensus as to the instrument to be used.

Wagering on functional disability as a reliable indicator of disability, it is possible to conclude that $24 \%$ to $49 \%$ of the population that survives stroke has some level of disability, which can vary according to age, stroke recurrence, time of evaluation and instrument applied. Most of the studies present disability by means of instruments that measure physical performance in activities of daily living, affirming functional disability as the most used indicator to define disability in people after suffering stroke. The Barthel Index was the instrument most used in the articles; however, the modified Rankin Scale was preferred to present results of disability.

\section{References}

1. Zivin JA. Abordagem das doenças cerebrovasculares. In: Goldman L, Ausiello D, editores. Cecil: tratado de medicina interna. 22. ed. Rio de Janeiro: Elsevier; 2005. p. 2667-70.

2. Roger VL, Go AS, Lloyd-Jones DM, Benjamin EJ, Berry JD, Borden WB, et al. Heart disease and stroke statistics - 2012 update: a report from the American Heart Association. Circulation. 2012;125(1):e2-e220.

3. Rosamond W, Flegal K, Furie K, Go A, Greenlund K, Haase $N$, et al. Heart disease and stroke statistics 2008 update: a report from the American Heart Association Statistics Committee and Stroke Statistics Subcommittee. Circulation. 2008;117(4): e25-146.

4. Miller EL, Murray L, Richards L, Zorowitz RD, Bakas T, Clark P, et al. Comprehensive overview of nursing and interdisciplinary rehabilitation care of the stroke patient: a scientific statement from the American Heart Association. Stroke. 2010;41(10):2402-48.
5. Carod-Artal FJ, Trizotto DS, Coral LF, Moreira CM. Determinants of quality of life in Brazilian stroke survivors. J Neurol Sci. 2009;284(1-2):63-8.

6. Coss P, Bell RMR, Armenteros JP, Batista LER. Índice de independencia de paciente con Accidente Vascular Encefálico. Rev Cubana Enferm. 2010;26(4):206-21.

7. Cerniauskaite M, Quintas R, Koutsogeorgou E, Meucci P, Sattin D, Leonardi M, et al. Quality-of-life and disability in patients with stroke. Am J Phys Med Rehabil. 2012;91(13 Suppl 1):39-47.

8. Nagi SZ. An epidemiology of disability among adults in the United States. Milbank Mem Fund Q Health Soc. 1976;54(4):439-67.

9. Organização Mundial da Saúde. CIF: Classificação Internacional de Funcionalidade, Incapacidade e Saúde. São Paulo: EDUSP; 2003. p. 13-32.

10. Alves LC, Leite IC, Machado CJ. Conceituando e mensurando a incapacidade funcional da população idosa: uma revisão de literatura. Ciênc Saúde Coletiva. 2008;13(4):1199-207.

11. Baptista DBDA. Idosos no município de São Paulo: expectativa de vida ativa e perfis multidimensionais de incapacidade a partir da SABE [dissertação]. Belo Horizonte: Universidade Federal de Minas Gerais; 2003.

12. Veerbeek JM, Kwakkel G, Van Wegen EE, Ket JC, Heymans MW. Early prediction of outcome of activities of daily living after stroke: a systematic review. Stroke. 2011;42(5):1482-8.

13. Tse T, Douglas J, Lentin P, Carey L. Measuring participation after stroke: a review of frequently used tools. Arch Phys Med Rehabil. 2013;94(1):177-92.

14. Castro AA, Saconato H, Guidugli F, Clarck OAC. Curso de revisão sistemática e metanálise [internet]. São Paulo: LED-DIS/UNIFESP; 2002 [cited 2015, Jun 2]. Available from: http://www.virtual.epm.br/cursos/ metanalise

15. Downs SA, Black N . The feasibility of creating a checklist for the assessment of the methodological quality both of randomised and non-randomised studies of health care interventions. J Epidemiol Community Health. 1998;52(6):377-84. 
16. Silva MC, Fassa AG, Domingues MR, Kriebel D. Gonalgia entre trabalhadores e fatores ocupacionais associados: uma revisão sistemática. Cad Saúde Pública. 2007;23(8):1763-75.

17. Martins T, Ribeiro JP, Garrett C. Disability and quality of life of stroke survivors: evaluation nine months after discharge. Rev Neurol. 2006;42(11):655-9.

18. Lo RS, Cheng JO, Wong EM, Tang WK, Wong LK, Woo J, et al. Handicap and its determinants of change in stroke survivors: one-year follow-up study . Stroke. 2008;39(1):148-53.

19. Patel MD, Tilling K, Lawrence E, Rudd AG, Wolfe CD, McKevitt C. Relationships between long-term stroke disability, handicap and health-related quality of life. Age Ageing. 2006;35(3):273-9.

20. Appelros P, Nydevik I, Terént A. Living setting and utilisation of ADL assistance one year after a stroke with special reference to gender differences. Disabil Rehabil. 2006;15;28(1):43-9.

21. Hankey GJ, Jamrozik K, Broadhurst RJ, Forbes S, Anderson CS. Long-term disability after first-ever stroke and related prognostic factors in the Perth Community Stroke Study, 1989-1990. Stroke. 2002;33(4):1034-40.

22. Hong KS, Saver JL, Kang DW, Bae HJ, Yu KH, Koo J, et al. Years of optimum health lost due to complications after acute ischemic stroke: disability-adjusted lifeyears analysis. Stroke. 2010;41(8):1758-65.

23. Hardie K, Hankey GJ, Jamrozik K, Broadhurst RJ, Anderson $\mathrm{C}$. Ten-year risk of first recurrent stroke and disability after first-ever stroke in the Perth Community Stroke Study. Stroke. 2004;35(3):731-5.

24. Quintas R, Cerniauskaite M, Ajovalasit D, Sattin D, Boncoraglio G, Parati EA, et al. Describing functioning, disability, and health with the International Classification of Functioning, Disability, and Health Brief Core Set for Stroke. Am J Phys Med Rehabil. 2012;91(13 Suppl 1):14-2.

25. Martins EF, Sousa PH, Barbosa PH, Menezes LT, Costa AS. A Brazilian experience to describe functioning and disability profiles provided by combined use of ICD and ICF in chronic stroke patients at home-care. Disabil Rehabil. 2011;33(21-22):2064-74.
26. Widar M, Ahlström G. Disability after a stroke and the influence of long-term pain on everyday life. Scand Journal Caring Sci. 2002;16(3):302-10.

27. Petrea RE, Beiser AS, Seshadri S, Kelly-Hayes M, Kase CS, Wolf PA. Gender differences in stroke incidence and poststroke disability in the Framingham heart study. Stroke. 2009;40(4):1032-7.

28. Gall SL, Dewey HM, Sturm JW, Macdonell RA, Thrift AG. Handicap 5 years after stroke in the North East Melbourne Stroke Incidence Study. Cerebrovasc Dis. 2009;27(2):123-30.

29. Lin JH, Tsai AY, Lo SK, Chang JJ, Huang MH. Predicting the grade of disability 1 year after stroke following rehabilitation. Kaohsiung J Med Sci. 2005;21(5):212-9.

30. Guccione AA. Fisioterapia geriátrica. Rio de Janeiro: Guanabara Koogan; 2002. p. 114-24.

31. Alves LC. Condições de saúde e a incapacidade funcional dos idosos no Brasil em 2003 [tese]. Rio de Janeiro: Fundação Oswaldo Cruz; 2008.

32. Federici S, Meloni F, Mancini A, Lauriola M, Olivetti Belardinelli M. World Health Organization Disability Assessment Schedule II: Contribution to the Italian validation. Disabil Rehabil. 2009;31(7):553-64.

33. Organização Mundial da Saúde. Envelhecimento ativo: uma política de saúde. Trad. Suzana Gontijo. Brasília: Organização Pan-Americana da Saúde; 2005.

34. Brasil. Ministério da Saúde. Secretaria de Atenção à Saúde. Envelhecimento e saúde da pessoa idosa. Brasília: Ministério da Saúde; 2006.

35. Jorgensen HS, Nakayama H, Raaschou HO, et al. Outcome and time course of recovery in stroke. Part 1: Outcome. The Copenhagen Stroke Study. Arch Phys Rehabil. 1995;76(5):399-405.

36. Wade DT, Hewer RL. Functional abilities after stroke: measurement, natural history and prognosis. J Neurol Neurosurg Psychiatry. 1987;50(2):177-82.

Received: 05/29/2014 Recebido: 29/05/2014

Approved: 03/03/2015 Aprovado: 03/03/2015 


\section{Annex 1}

Data collection form

Information of studies included

Title:

Publication date:

References:

Methods

Research Question:

Objective:

Study type:

Instrument used to determine outcomes:

Study location:

Sample representation:

Calculation of statistical power:

\section{Participants}

Age:

Sex:

Inclusion criteria:

Exclusion criteria:

Diagnostic criteria:

Number of participants:

Outcomes

Results 